\title{
Artropatía gotosa
}

\section{Gouthy arthritis}

\section{Kenny Buitrago-Toro ${ }^{1,2,3, a, b}$, Silvana Jiménez-Salazar ${ }^{1,2,3, a, b}$}

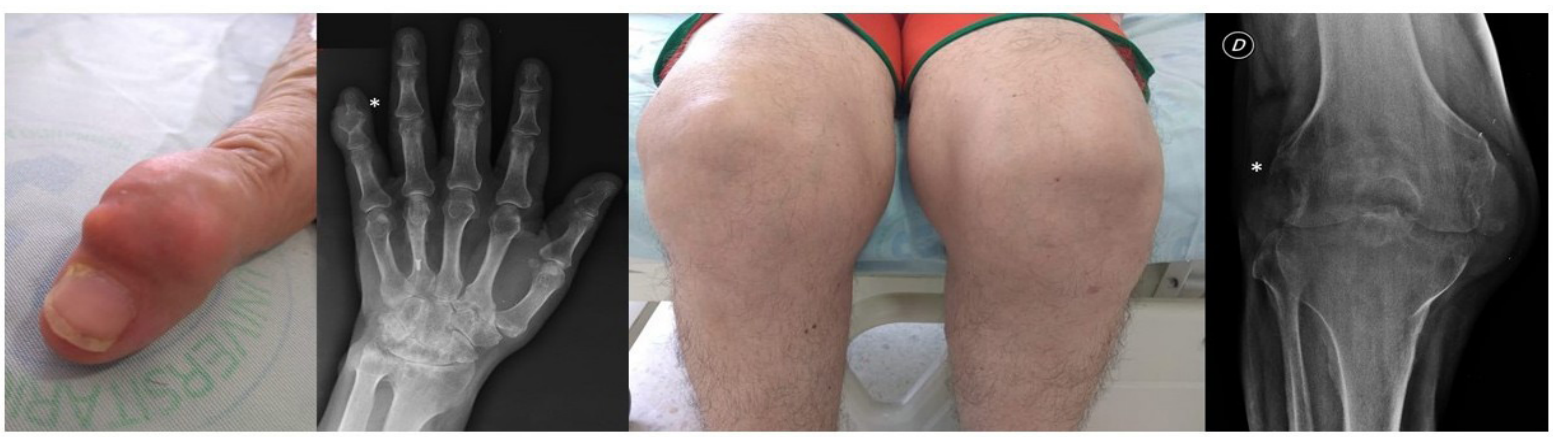

Varón de 58 años de edad, consulta por dolor en rodilla derecha, evidenciándose deformidad y aumento de tamaño respecto a la rodilla contralateral. Además, presentaba tofos en el quinto dedo de la mano izquierda y niveles de ácido úrico elevados. Las radiografías evidenciaron erosiones óseas en sacabocado con bordes escleróticos típico de la artropatía gotosa. La gota es una enfermedad crónica caracterizada por ataques recurrentes de dolor e inflamación articular debido a la acumulación de cristales de urato monosódico y a largo plazo la formación de tofos. En estadios iniciales la lesión ósea puede no ser evidente en la radiografía simple y solo demostrarse inflamación de tejidos blandos. De no ser tratada correctamente, se desarrollan lesiones típicas como erosiones óseas redondeadas con bordes escleróticos sobresalientes en aspecto de sacabocados. Generalmente el espacio articular es respetado incluso en fases avanzadas de la enfermedad.

58-year-old male patient who presented with pain on the right knee, the physical examination revealed a deformed and swollen right knee and presence of tophus on the fifth finger of the left hand, the serum uric acid levels were elevated. A plain film of the hands showed bone erosions and sclerotic borders typical of gout arthropathy. Gout is a chronic disease characterized by recurrent attacks of articular pain and inflammation due to the deposit of monosodium urate crystals leading to the formation of tophus in the long term. In early stages of the disease the bone involvement may not be visible, but if not properly treated bone affection occurs anyway. The articular space in spare even at advance stages of the disease.

\section{Correspondencia:}

Silvana Jimenez-Salazar

Neiva, Colombia.

Zip code 410010

email: silvana1212@gmail.com

\footnotetext{
Hospital Universitario Hernando Moncaleano Perdomo. Neiva, Colombia

Universidad Surcolombiana. Neiva, Colombia.

Grupo de investigación MI Dneuropsy, Universidad Surcolombiana. Neiva, Colombia.

Residente de Medicina Interna

Semillero de investigación en medicina interna (SIMI).
} 